\title{
Dutch universities fight plan to cut teaching and research
}

\section{Patent office braces itself for report on costs and staffing}

Munich. The Munich-based European Patexcessive costs and centralization, last week extended the term of office of its president Paul Braedli to give itself more time to appoint his successor.

Braedli, who has already served two fiveyear terms as president, is not standing for a third term as he is approaching retirement age. His appointment, due to expire next May, will instead be extended until the end of 1995, while the EPO council considers three candidates as his successor.

Whatever the outcome, the new president will arrive at a politically sensitive time for the office. He or she will be faced with the results of a investigation currently being carried out by EPO's administrative council, made up of representatives from each of its 17 member states, whose report should be completed by the middle of next year.

The investigation was prompted by the unhappiness of some member states over issues such as the cost of patenting through the EPO, the lower than expected ratio of European to non-European patent applications, and the desire that some of the EPO's activities be decentralized to national patent offices.

Much debate has been generated by the relatively high, tax-free salaries enjoyed by the EPO's 4,000 staff, particularly locally in Bavaria, where politicians have campaigned for an end to the tax-free status of employees. The report may suggest that staff and accommodation costs be reduced over the next few years.

The investigation is also looking at ways of reducing high translation costs that add at least 20 per cent to every patent application. Both issues are politically very sensitive.

It was hoped that applications from Europe would constitute at least two-thirds of the total. In fact these make up only half. One way of improving this ratio may be to decentralize patent information services to national offices.

A. A. ent Office (EPO), faced with complaints of

Munich. The Netherlands could become the first mainland European country to abandon the continental system of university education under government proposals to move to a cheaper Anglo-Saxon system, with shorter undergraduate degree courses.

But Dutch academics are fighting the proposals. They are also resisting the government's efforts to cut back heavily on university and research funding as part of a package of across-the-board cuts intended to trim F11 8 billion (US $\$ 10.26$ billion) from public spending over the government's fouryear term of office.

Addressing the opening session of the new Dutch Parliament last week, Wim Kok, the prime minister and head of the country's left-of-centre coalition, announced plans to cut Fl1.5 billion from the universities budget of the Ministry of Education and Science.

The government wants F11 billion of this to come from the country's generous system of student support.

It argues that this could be done by moving to a two-tier degree system similar to that in the United States and the United Kingdom, in which a three-year bachelor degree is followed by a masters degree only for those students with a specific interest in further studies.

At present, a Dutch degree officially requires four years of study. But students tend to spend up to six years completing a degree course, which includes a significant research component.

The government argues that as well as saving money, the proposed change would give Dutch graduates a better chance of finding jobs outside the Netherlands, as they would leave university earlier and, for example, fit more easily into the job market in the United States.

But the proposal does not have universal support. A meeting of university heads last week expressed alarm at the proposal, warning of the danger of linking academic reform to spending cuts. Such officials argue

\section{Research to benefit from ex-communist funds}

Munich. Science in the former German Democratic Republic is set to benefit from a share of a large fund which has finally been released from the coffers of the PDS (Partei des demokratischen Sozialismus), the official successor to former East Germany's communist party.

The German government had been trying to get its hands on the money since reunification, arguing that the money had been wrongfully accumulated. Last week, after several months of negotiation, the
PDS agreed to release DM1.1 billion (US\$705 million) to support the 'cultural base' of the new Länder.

DM150 million of this sum has been allocated to science, half of which will be distributed by the five new Länder governments. The rest of the money is being used by the federal government to support the development of new products in the Länder. A call for research grant applications was put out last month in anticipation of the settlement. that the Anglo-Saxon system is not appropriate to an educational system which guarantees university education to all students with a high-school diploma.

The Netherlands' Research Council (NWO) is also campaigning against the proposal, claiming that it will damage the research potential of the Netherlands by lowering standards of higher education.

The council also argues that the additional cut of F1500 million to universities will mean a loss of 10,000 academic jobs equivalent to a 15 per cent fall in university staffing - which will inevitably have a direct effect on research.

But the Netherlands is not the only European country to flirt with ideas of academic reform.

Many others, particularly Germany, are starting to believe that the ideal of guaranteeing university education for all highschool certificate holders, with little control over the length of their studies, is a luxury which has no place in the 1990s.

As part of the same austerity package, a further F1700 million is expected to be cut from the research budgets of other ministries during the government's four-year term of office.

Details will be announced by the government on 20 September. But science organizations are fearing the worst. Frans Gubbi, a director of the Dutch applied research organization, the TNO, fears that the government will reduce TNO's basic budget of around F1200 million annually by 10 per cent, a move that could hit environmental and energy programmes particularly hard.

TNO depends heavily on contract research, which brings in around F1500 million annually. Gubbi says that this income will be seriously affected by government cuts to ministries, and that the new cabinet's policy may mean that the organization is unable to keep its basic functions running, with the potential loss of hundreds of research jobs.

The Dutch Social and Economic Council, made up of representatives of industry and the economics community, recently advised the government to raise research spending by F11 billion in order to stop it falling further behind its European neighbours. (Spending on research and development has fallen from a high of 2.3 per cent of gross national product in the 1980 s to 1.87 per cent in 1993.)

"Instead they are cutting back further," says Gubbi, who is organizing a major lobby of ministers, civil servants and parliament during the budget debates over the next two months in an attempt to reverse government policy.

Alison Abbott 